\title{
PENGARUH AUDIT OPERASIONAL DALAM MENINGKATKAN EFEKTIFITAS DAN EFESIENSI PELAYANAN KESEHATAN PEGAWAI RUMAH SAKIT UMUM DAERAH SELASIH KABUPATEN PELALAWAN
}

\author{
Mulia Sosiady dan Ermansyah \\ Dosen Fakultas Ekonomi dan Ilmu Sosial UIN Sultan Syarif Kasim Riau
}

\begin{abstract}
Abstrak
Penelitian ini bertujuan untuk mengetahui apakah ada pengaruh audit operasional terhadap efektifitas dan efisiensi pelayanan kesehatan di Rumah Sakit Umum Daerah Selasih Pelalawan dengan menggunakan metode purposive sampling, terdapat 60 sampel responden dari seluruh akuntan, staff akuntan, staff, dokter jaga/perawat. Melalui instrumen penelitian yang berupa lembaran daftar pernyataan. Jenis data yang dipakai adalah data primer dan data sekunder.

Metode analisis data yang digunakan Regresi Linear Sederhana, dengan pengujian analisis data yang digunakan adalah uji validitas, uji realibilitas, uji normalitas, uji asumsi klasik dan statistik deskriptif. Pengujian hipotesis yang digunakan adalah uji signifikan parsial (uji t) dan koefisien determinasi. Hasil penelitian ini menunjukkan bahwa pengaruh audit operasional berpengaruh secara signifikan terhadap efektifitas dan efisiensi pelayanan kesehatan. Hasil analisa regresi secara keseluruhan menunjukkan nilai $R$ sebesar 0.748 yang berarti bahwa Audit Operasional berpengaruh kuat terhadap efektifitas dan efesiensi pelayanan kesehatan Rumah Sakit Umum Daerah Selasih Pelalawan sebesar 74.8\%.
\end{abstract}

\section{Kata Kunci : Audit Operasional, Pelayanan Rumah Sakit, RSUD Selasih Pelalawan}

\section{PENDAHULUAN}

Rumah Sakit Umum Daerah Selasih Kabupaten Pelalawan merupakan salah satu rumah sakit terunggul di Pantai Timur Sumatera yang modern dengan nuansa melayu. Hingga saat ini Rumah Sakit Umum Daerah Selasih Kabupaten Pelalawan menjadi rumah sakit rujukan dari dua Kabupaten yaitu Kabupaten Pelalawan dan Kabutan Indragiri Hulu. Sesuai dengan visi nya Rumah Sakit Umum Daerah Selasih Kabupaten Pelalawan menerapkan sendi-sendi pelayanan prima dapat diartikan sebagai pelayanan kesehatan yang bermutu dan berorientasi kepada pelanggan. Sama halnya dengan pelayanan kesehatan tidak lepas dari efektifitas dalam menjalankan pelayanan terhadap pasien.

Audit operasional sebagai bagian dari fungsi pengendalian merupakan salah satu alat bagi manajemen untuk mengukur dan mengevaluasi kegiatan yang telah dilaksanakan.Audit Operasional atas kegiatan pelayanan jasa yang dilaksanakan oleh BPK selaku tim auditor yang dilakukan pengawasan atau pemeriksaan setahun sekali. PadaRumah Sakit Umum Daerah Selasih Kabupaten Pelalawan dapat dilihat bahwa ruang Rumah Sakit Umum Daerah Selasih Kabupaten Pelalawan tampak terlihat kurangnya pelayanan yang maksimal dan kurang cepat tanggap dalam menangani jiwa pasien. Hal ini merupakan tugas penting bagi BPK selaku tim audit dalam melakukan pengawasan atau pemeriksaan lebih ketat dengan cara memberikan perbaikan-perbaikan atau rekomendasi untuk dapat memperbaiki kualitas pelayanan kesehatan yang cepat dan tepat dalam penanganan dan meningkatkan kualitas kinerja yang efektif dan efisien.

Menurut (Dan M.Guy, 2003) Audit Operasional secara umum bertujuan untuk memeriksa apakah pelaksanaan suatu kegiatan yang telah dilaksanakan sesuai dengan apa yang diharapkan (dicapai) dan 
apabila didalam audit tersebut ditemukan hal-hal yang menyimpang dari apa yang diharapkan, maka pemeriksa melaporkan temuan-temuan tersebut kepada manajemen dan memberikan rekomendasi untuk tindakan perbaikan dan penyempurnaan. Pihak manajemen yang berkepentingan langsung dengan pemeriksaan tersebut harus menerima setiap hasil pemeriksaan dan segera melakukan tindakan perbaikan yang diperlukan sehingga setiap kegiatan yang dilaksanakan dapat berjalan secara efektif dan efisien.

Audit Operasinal atas pelayanan kesehatan unit gawat darurat di Rumah Sakit Umum Daerah Selasih Kabupaten Pelalawan dilaksanakan oleh Tim BPK (Badan Pemeriksa Keuangan). BPK merupakan lembaga tinggi negara dalam sistem ketatanegaraan Indonesiayang memiliki wewenang memeriksa pengelolaan dan tanggung jawab keuangan negara. Audit Operasional tersebut dilakukan secara periodik, yaitu setahun sekali pemeriksaan (pertahun).

Dalam hal ini peneliti membatasi diri pada salah satu aktivitas dan resiko tertinggi yang dihadapi oleh rumah sakit, yaitu aktivitas penjualan jasa dalam bentuk pelayanan kesehatan,dalam. Dimana pada unit kesehatan ini diharapkan adanya pelayanan yang cepat dan tepat dalam penanganan, terutama pertolongan pertama yang dilakukan untuk menyelamatkan jiwa pasien.

Tujuan dilakukannya penelitian ini adalah sebagai berikut : Untuk mengetahui Apakah ada pengaruh peranan audit operasional terhadap efektifitas dan efisiensi pelayanan kesehatan Rumah Sakit Umum Daerah Selasih Kabupaten Pelalawan

\section{Manfaat Penelitian}

\section{- Bagi Peneliti}

Memperoleh informasi dan ilmu pengetahuan yang memperluas wawasan mengenai audit operasioanal dan penelitian ini diharapkan dapat menjadi kesempatan bagi peneliti untuk menerapkan teori-teori yang diperoleh dibangku kuliah.

- Bagi Rumah Sakit

Peneliti berharap dapat memberikan informasi, masukan dan saran yang bermanfaat bagi pengelola rumah sakit untuk pertimbangan dalam audit operasional.

- Bagi Universitas

Diharapkandapat berguna sebagai tambahan informasi dan pengetahuan serta sekaligus menjadi suatu sumber pemecahan masalah mengenai audit operasional atas pelayanan kesehatan Rumah Sakit.

Pada dasarnya pemeriksaan atau yang lebih dikenal dengan istilah audit bertujuan untuk menilai apakah pelaksanaan sudah selaras dengan apa yang telah digariskan, maka dapat disimpulkan bahwa audit merupakan suatu proses membandingkan antara kenyataan dengan seharusnya.Untuk mengetahui dengan jelas pengertian audit, maka berikut ini akan dikemukakan definisidefinisi pengauditan yang diambil dari beberapa sumber yaitu:

Menurut Agus Sukrisno 2004 Suatu pemeriksaan yang dilakukan secara kritis dan sistematis oleh pihak yang independen, terhadap laporan keuangan yang telah disusun oleh manajemen beserta catatan-catatan pembukuan dan bukti-bukti pendukungnya, dengan tujuan untuk dapat memberikan pendapat mengenai kewajaran laporan keuangan tersebut. Menurut Arens dan Loebbecke, 2003, auditing sebagai: Suatu proses pengumpulan dan pengevaluasian bahan bukti tentang informasi yang dapat diukur mengenai suatu entitas ekonomi yang dilakukan seorang yang kompeten dan independen untuk dapat menentukan dan melaporkan kesesuaian informasi dengan kriteria-kriteria yang telah ditetapkan. Auditing seharusnya dilakukan oleh seorang yang independen dan kompeten.

Menurut Mulyadi, 2002, auditing merupakan Suatu proses sistematik untuk 
memperoleh danmengevaluasi bukti secara objektif mengenai pernyataan-pernyataan tentang kegiatan dan kejadian ekonomi dengan tujuan untuk menetapkan tingkat kesesuaian antara pernyataan-pernyataan tersebut dengan kriteria yang telah ditetapkan, serta penyampaian hasilhasilnya kepada pemakai yang berkepentingan.

\section{Jenis-jenis Audit}

Menurut Sukrisno Agus, 2004 ditinjau dari luasnya pemeriksan, maka audit dapat dibedakan atas:

a. Pemeriksaan Umum (General Audit), yaitu suatu pemeriksaan umum atas laporan keuangan yang dilakukan oleh Kantor Akuntan Publik (KAP) yang independen dengan maksud untuk memeberikan opini mengenai kewajaran laporan keuangan secara keseluruhan.

b. Pemeriksaan Khusus (Special Audit), yaitu suatu bentuk pemeriksaan yang hanya terbatas pada permintaan audit yang dilakukan oleh Kantor Akuntan Publik (KAP) dengan memberikan opini terhadap bagian dari laporan keuangan yang diaudit, misalnya pemeriksaan terhadap penerimaan kas perusahaan.

Masih menurut sumber yang sama, menurut Sukrisno Agus, 2004, ditinjau dari jenis pemeriksaan maka audit dapat dibedakan atas:

a. Audit Operasional (Management Audit), yaitu suatu pemeriksaan terhadap kegiatan operasi suatu perusahaan, termasuk kebjakan akuntansi dan kebijakan operasional yang telah ditetapkan oleh manajemen dengan maksud untuk mengetahui apakah kegiatanoperasi telah dilakukan secara efektif, efisien, dan ekonomis.

b. Pemeriksaan Ketaatan (Complience
Audit), yaitu suatu pemriksaan yang dilakukan untuk mengetahui apakah perusahaan telah menaati peraturan-peraturan dan kebijakankebijakan yang berlaku, baik yang ditetapkan oleh pihak intern perusahaan maupun pihak ekstern perusahaan.

c. Pemeriksaan Intern (Internal Audit), yaitu pemeriksaan yang dilakukan oleh bagian internal audit perusahaan yang mencakup laporan keuangan dan catatan akuntansi perusahaan yang bersangkutan serta ketaatan terhadap kebijakan manajemen yang telah ditentukan.

d. Audit Komputer (Computer Audit), yaitu pemeriksaan yang dilakukan oleh Kantor Akuntan Publik (KAP) terhadap perusahaan yang melakukan proses data akuntansi dengan menggunakan sistem Elektronik Data Processing (EDP)

\section{Standar Audit yang Berlaku Umum}

Standar Auditing merupakan pedoman bagi auditor dalam menjalankan tanggug jawab profesionalnya Ikatan Akuntan Indonesia (IAI) dalam Persyaratan Standar Auditing (PSA) No. 1 telah menetapkan dan menesahkan sepuluh auditing yang dibagi menjadi tiga kelompok, yaitu:

1. Standar Umum, berfungsi untuk mengatur syarat-syarat diri audior. Standar umum terdiri dari:

a. Audit harus dilasanakan oleh seorang atau lebih yang memiliki keahlian danpelatihan teknis yang cukup sebagai auditor.

b. Dalam semua hal yang berhubungan dengan perikatan, independensi dalam sikap mental harus dipertahankan oleh auditor.

c. Dalam pelaksanaan audit dan pelaporannya, auditor wajib menggunakan kemahiran 
profesionalnya dengan cermat dan seksama.

2. Standar Pekerjaan lapangan, berfungsi untuk mengatur mutu pelaksanaan auditing. Standar pekerjaan lapangan terdiri dari:

a. Pekerjaan harus dilaksanakan sebaik-baiknya dan jika digunakan sistem harus disupervisi dengan semestinya.

b. Pemahaman memadai atas Struktur Pengendalian Intern (SPI) harus diperoleh untuk merencanakan audit dan menentukan sifat, saat dan lingkup pengujian yang akan dilakukan.

c. Bukti audit kompeten yang cukup harus diperoleh melalui inspeksi, pengamatan, permintaan keterangan dan konfirmasi sebagai dasar memadai untuk menyatakan pendapat atas laporan keuangan yang diaudit.

3. Standar pelaporan, berfungsi sebagai panduan bagi auditor dalam mengkomunikasikan hasil audit melalui laporan audit kepada pemakai informasi keuangan. Standar pelaporan terdiri dari:

a. Laporan auditor harus menyatakan apakah laporan keuangan telah disusun sesuai Prinsip Akuntansi yang Berlaku Umum (PABU) di Indonesia.

b. Laporan auditor harus menunjukkan atau menyatakan, jika ada ketidakkonsistenan penerapan prinsip akuntansi dalam menyusun laporan keuangan periode berjalan dibandingkan dengan prinsip akuntansi tersebut dalam periode sebelumnya.

c. Pengungkapan informatif dalam laporan keuangan harus dipandang memadai, kecuali dinyatakan lain dalam laporan auditor. d. Laporan auditor, harus memuat suatu pernyataan pandapat mengenai laporan keuangan secara keseluruhan atau suatu asersi bahwa pernyataan demikian tidak dapat diberikan. jika pendapat secara keseluruhan tidak dapat diberikan, maka alasannya harus memuat petunjuk yang jelas mengenai sifat pekerjaan audit yang dilaksanakan, jika ada dan tingkat tanggung jawab yang dipikul oleh auditor.

\section{Audit Operasional}

Banyak definisi dari audit operasional yang mencakup penyebutan efficiency (pengeluaran yang minimum dari sumber daya), effectiveness (pencapaian hasil yang diinginkan) dan economy (kriteria dari suatu entitas). Dalam artikulasi yang berbeda, audit operasional dikenal sebagai audit manajemen. Perbedaan antara kedua istilah tersebut tidak jelas dan sering digunakan secara bergantian.

Menurut Guy dkk $(2003,419)$ audit operasional merupakan penelaahan atas prosedur dan metode operasi entitas untuk menetukan tingkat efisiensi dan efektivitasnya. Pada kesimpulan tentang audit operasional, rekomendasi yang umumnya diberikan adalah memperbaiki prosedur. Audit operasional kadangkadang disebut audit kinerja, audit manajemen, atau audit komprehensif.

Menurut Mulyadi 2002, pengertian audit operasional adalah: "Audit operasional merupakan suatu review secara sistematis mengenai kegiatan organisasi atau bagian dari padanya dalam hubungannya dengan tujuan tertentu".

\section{Metode Penelitian}

1. Lokasi dan Waktu Penelitian Adapun lokasi penelitian ini adalah di Rumah Sakit Umum Daerah Selasih Kabupaten Pelalawan Jln Townsite II 
2. Populasi Dan Sampel

Populasi

Sebagai populasi data penelitian ini adalah seluruh akuntan, staff akuntan, staff UGD, dokter jaga/perawat pada Rumah Sakit Umum Daerah Selasih Kabupaten Pelalawan yang berjumlah 40 orang.

Sampel

Pengambilan sampel penelitian menggunakan metode sensus dimana sampel yang diambil adalah seluruh jumlah populasi yang berjumlah 40 orang

3. Teknik Pengumpulan Data

- Wawancara yaitu mengajukan pertanyaan-pertanyaan yang telah dipersiapkan terlebih dahulu secara tertulis maupun lisan mengenai masalah-masalah yang akan diteliti kepada karyawan perusahaan.

- Observasi atau pengamatan langsung untuk mendapatkan data dan informasi yang dibutuhkan.

- Kuesioner, Kuesioner yang dilakukan peneliti dalam pegumpulan data terdiri dari dua bagian, yaitu:

Pertanyaan umum, adalah pertanyaan yang menyangkut identitas umum responden

Pertanyaan Khusus, adalah pertanyaan yang berkaitan dengan pengaruh audit operasional dalam mendorong efektifitas dan efesiensi pelayanan kesehatan Rumah sakit.

\section{Teknik Analisis Data}

Uji Kualitas Data

Uji Validitas

Berikut ini adalah kriteria pengujian validitas:

Jika $r$ hitung $\geq \mathrm{r}$ tabel (uji 2 sisi dengan sig.0,05) maka instrumen atau item-item pertanyaan berkorelasi signifikan terhadap skor total (dinyatakan valid)

Jika $r$ hitung $<r$ tabel (uji 2 sisi dengan sig.0,05) maka instrumen atau item-item pertanyaan tidak berkorelasi signifikan terhadap skor total (dinyatakan tidak valid).

\section{Uji Realibilitas}

Uji Reabilitas adalah untuk mengetahui konsistensi alat ukur, apakah alat pengukur yang digunakan dapat diandalkan dan tetap konsisten jika pengukuran tersebut diulang. Untuk uji realibilitas digunakan Teknik Alpha Cronbach, dimana suatu instrument dapat dikatakan handal (reliable) bila memiliki koefisien kenadalan atau alpha sebesar 0,6 atau lebih.

Uji Asumsi Dasar

a. Uji Normalitas Data

Uji normalitas data adalah untuk mengetahui apakah populasi data berdistribusi normal atau tidak. Alat yang dapat digunakan dalam menguji distribusi normal data adalah Uji KolmogorovSmirnov.

\section{Uji Asumsi Klasik'}

a. Uji Heteroskedastisitas

Uji Heteroskedastisitas digunakan untuk menegetahui ada atau tidaknya penyimpangan asumsi klasik heteroskedastisitas, yaitu adanya ketidaksamaan varian dari residual untuk semua pengamatan pada model regresi

\section{Analisis Regresi Berganda}

Analisis regresi linier sederhana adalah hubungan secara linear antara satu variabel independen $(\mathrm{X})$ dengan variabel dependen (Y). Analisis ini untuk mengetahui arah hubungan antara variabel independen dengan variabel dependen apakah positif atau negatif dan untuk memprediksi nilai dari variabel dependen apabila nilai variabel independen mengalami kenaikkan atau penurunan.

Rumus regresi linear sederhana sebagai berikut:

$\mathrm{Y}=\mathrm{a}+\mathrm{bX}$

\section{Variabel enelitian}

Variabel yang digunakan dalam penelitian ini adalah:

Variabel Dependent : Y Pelayanan 
Variabel Independent : X Audit Operasional

\section{HASIL DAN PEMBAHASAN \\ 1. Uji Validitas}

Salah satu cara untuk menguji validitas yang dikembangkan adalah dengan membandingkan nilai $r_{\text {hitung }}$ dengan $r_{\text {tabel }}$ untuk degree of freedom $(\mathrm{df})=\mathrm{n}$, dalam hal ini $\mathrm{n}$ adalah jumlah sampel. Pada penelitian ini sampel berjumlah 40. Sehingga dalam penelitian ini besarnya $\mathrm{df}$ dapat dihitung sebesar dengan df 40 maka diperoleh $\mathrm{r}_{\text {tabel }}$ sebesar $0.334(\alpha=5 \%)$.

\section{Uji Reliabilitas}

\section{Reliability Statistics}

\begin{tabular}{|r|l|}
\hline Cronbach's Alpha & N of Items \\
\hline .933 & 15 \\
\hline
\end{tabular}

Sumber : Hasil Olahan Data

SPSS 16

Berdasarkan tabel IV.7 di atas, terlihat bahwa nilai Croanbach's

\section{Analisis Regresi Berganda}

\section{Regresi Linear Sederhana}

Coefficients $^{\mathrm{a}}$

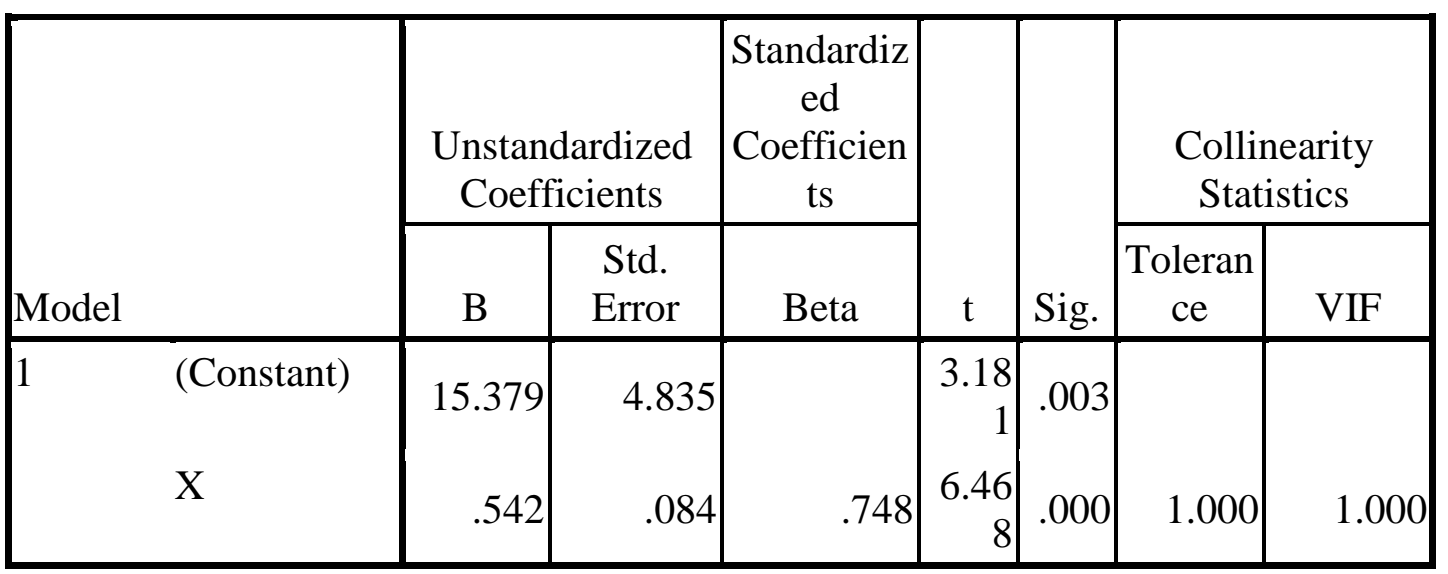

a. Dependent Variable: Y

\section{Sumber : Hasil Data Olahan SPSS 16}

Persamaan regresi dari hasil perhitungan statistik didapat sebagai berikut: $\mathrm{Y}=15.379+0.542 \mathrm{X}$
Alpha Audit Operasional sebesar 0.933. hal ini berarti bahwa, nilai ini telah melewati syarat untuk realibilitas karena memiliki korelasi > dari 0.6 atau di atas $60 \%$. Maka dapat dikatakan bahwa Audit Operasional teruji relibilitasnya.

\section{Reliability Statistics}

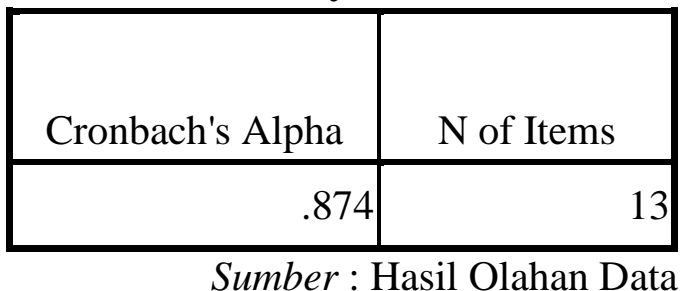

SPSS 16

Setelah dilakukan pengujian relibilitas pada variabel Pelayanan Kesehatan UGD terlihat bahwa instrumen ini memenuhi syarat untuk relibilitas karena memiliki korelasi > dari 0.6 atau di atas $60 \%$ yaitu menunjukkan Cronbach's Alpha 0.874. 
tersebut adalah:

Arti persamaan regresi linier

a. Konstanta sebesar 15.379 menyatakan bahwa jika variabel independen tetap, maka variabel dependen adalah sebesar 15.379.

b. Koefisien $X=0.542$, menunjukkan bahwa peranan auditoperasional berpengaruh positif terhadap efektifitas dan efisiensi pelayanan kesehatan UGD (Y). Artinya, jika setiap kali variabel Peranan Audit Operasional (X) bertambah satu, maka variabel efektifitas dan efisiensi pelayanan kesehatan UGD (Y) akan bertambah sebesar 0.542 .

\section{Koefesien Determinan}

\begin{tabular}{|l|r|r|r|r|r|}
\hline \multicolumn{7}{|c|}{ Model Summary } \\
\hline Model & R & R Square & $\begin{array}{c}\text { Adjusted R } \\
\text { Square }\end{array}$ & $\begin{array}{l}\text { Std. Error of } \\
\text { the Estimate }\end{array}$ & $\begin{array}{c}\text { Durbin- } \\
\text { Watson }\end{array}$ \\
\hline 1 & .748 & .559 & .546 & 5.556 & 1.994 \\
\hline
\end{tabular}

a. Predictors: (Constant), X

b. Dependent Variable: Y

Sumber: Hasil Olahan Data SPSS 16

Berdasarkan tabel IV.14 diperoleh nilai $\mathrm{R}$ sebesar 0.748 yang berarti bahwa hubungan antara Pengaru Audit Operasional terhadap Pelayanan kesehatan UGD mempunyai hubungan yang kuat sebesar $74.8 \%$ dikatakan kuat karena angka tersebut di atas 0.5 atau $50 \%$.dan nilai $\mathrm{R}$ Square sebesar 0.559 atau $55.9 \%$ yang berarti bahwa variasi atau perubahan variabel dependen (Efektifitas dan efisiensi pelayanan kesehatan UGD) mampu dijelaskan oleh variasi atau perubahan variabel independen (Peranan Audit Operasional) sebesar 0.559 atau $55.9 \%$. Sedangkan sisanya sebesar $44.1 \%$ dipengaruhi atau dijelaskan oleh variabel lain yang tidak dimasukkan dalam model penelitian ini.

Berdasarkan pengujian yang telah dilakukan, maka diperoleh hasil penelitian ini menunjukkan Audit Operasional berpengaruh terhadap Pelayanan Kesehatan Rumah Sakit Umum Daerah Selasih Kabupaten Pelalawan.

\section{PENUTUP}

1. Secara umum hasil pengujian validitas dan realibilitas item pernyataan penelitian telah memberikan hasil

yang baik. Koefisisen realibilitas menunjukkan nilai cronbach's alphavariabel X 0.933 dan variabel Y 0.874 . Pengujian validitas terhadap seluruh item pernyataan dengan menggunakan corrected item-total correlation menunjukkan bahwa itemitem pernyataan dinyatakan valid.

2. Normalitas rata-rata jawaban responden yang menjadi data dalam penelitian ini dilihat dari KolmogorofSmirnov yang menunjukkan bahwa jawaban responden terdistribusi secara normal.

3. Hasil regresi secara parsial menunjukkan bahwa variabel Audit Operasional secara statistik Thitung>Ttabel $\quad(6.468>1.692)$ yang berarti Ho ditolak. Dengan demikian dapat disimpulkan bahwa Peranan audit operasional berpengaruh signifikan terhadap efektifitas dan efisiensi pelayanan kesehatan UGD.

4. Nilai $\mathrm{R}$ Square dari penelitian ini adalah sebesar 0.559 atau $55.9 \%$ yang berarti bahwa variasi atau perubahan variabel dependen (Efektifitas dan efisiensi pelayanan kesehatan UGD)mampu dijelaskan oleh variasi 
atau perubahan variabel independen (Peranan Audit Operasional) sebesar 0.559 atau $55.9 \%$.

\section{Saran}

1. Penelitian selanjutnya diharapkan dapat memperluas wilayah penelitian agar dapat diperoleh hasil genelisir yang lebih baik.

2. Manajemen beserta Dewan Komisaris harus memberikan dukungan penuh terhadap auditor operasional agar dapat menjalankan tugasnya dengan baik, salah satunya dengan mengadakan pelatihan dan program pendidikan bagi auditor operasional untuk meningkatkan fungsi dan tugasnya sebagai bagian auditor operasional.

3. Untuk menghasilkan hasil empiris yang kuat, penelitian ini perlu dikembangkan lebih lanjut lagi dengan menambah variabel faktor-faktor individual yang mempengaruhi peningkatan efektifitas dan efisiensi pelayanan kesehatan UGD.

4. Diharapkan kepada RSUD Selasih Kabupaten Pelalawan agar pasien mendapatkan pelayanan yang bermutu demi tercapainya peningkatan efektifitas dan efsiensi pelayanan kesehatan.

\section{DAFTAR PUSTAKA}

Agoes, Sukrisno. 2004. Auditing (Pemeriksaan Akuntan oleh Kantor Akuntan Publik). Edisi ketiga. Jakarta : Fakultas Ekonomi Universitas Indonesia. Jilid I

Aren,Lobbecke. 2003. Auditing. Jakarta:Salemba Empat

Dan M.Guy. 2001.Auditing. Jakarta : Penerbit Erlangga

Ikatan Akuntan Indonesia. 2001. Standar Profesional Akuntan Publik, Jakarta:Salemba Empat

Mulyadi. 2002. Auditing. Jakarta:Salemba Empat

Sugiyono. 2007. Metode Pnelitian Bisnis. Bandung: Penerbit Alfabeta

Undang-Undang No.44 tahun 2009 tentang
Rumah Sakit

Widjayanto,Nugroho. 2001. Pemeriksaan Operasional Perusahaan. Jakarta: Lembaga Penerbit Fakultas Ekonomi Universitas Indonesia 